This PDF is a selection from an out-of-print volume from the National Bureau of Economic Research

Volume Title: Economics of the Family: Marriage, Children, and Human Capital

Volume Author/Editor: Theodore W. Schultz, ed.

Volume Publisher: University of Chicago Press

Volume ISBN: 0-226-74085-4

Volume URL: http://www.nber.org/books/schu74-1

Publication Date: 1974

Chapter Title: Home Investments in Children

Chapter Author: Arleen Leibowitz

Chapter URL: http://www.nber.org/chapters/c2974

Chapter pages in book: (p. 432 - 456) 


\section{Home Investments in Children}

\section{Arleen Leibowitz}

National Bureau of Economic Research and Brown University

By the time children enter first grade, significant differences in verbal and mathematical competence exist among them. ${ }^{1}$ These differences reflect variations in (1) inherent ability, and (2) the amounts of human capital acquired before the children reach the age of six. ${ }^{2}$ The stocks of acquired human capital reflect, in turn, varying inputs of time and other resources by parents, teachers, siblings, and the child. The process of acquiring preschool human capital is analogous to the acquisition of human capital through schooling or on-the-job training.

Assuming a constant rental rate for human capital, earnings can be interpreted as a measure of capital stocks at later ages. The IQ also can be interpreted as such a measure of human capital stocks. It is related to some commonly used inputs of human capital, for it is well known that measured IQ is not independent of years of schooling acquired before the age of testing. At preschool ages IQ measures should be related to human capital inputs in early childhood as well as to inherent genetic ability.

Viewing measured ability as an index of the stock of human capital puts a different light on earnings functions which include ability and schooling. If contemporaneous ability and schooling measures are used to predict earnings (as in Hansen, Weisbrod, and Scanlon 1970), it is not surprising to find that earnings are more closely related to an ability measure, which

This research has been supported by grants to the National Bureau of Economic Research from the Office of Economic Opportunity and the National Institutes of Health. A National Science Foundation grant to the National Bureau of Economic Research funded the data preparation. I gratefully acknowledge the very competent research assistance of David L. Lindauer and Arun K. Mukhopadhyay. For helpful comments on a previous draft of this paper I thank Charles Betsey, Barry Chiswick, John Hause, Jacob Mincer, and Finis Welch.

1 This is one of the important findings of the Coleman Report (see Mosteller [1972, p. 49]).

2 Genetic factors cannot account for the entire difference, as studies of identical twins show. In one such study, identical twins raised apart showed an average difference in IQ of 14 points (Kagan 1969, p. 275). 
is an index of human capital stocks, than to years of schooling, which is merely a partial measure of one of the inputs. In this respect familybackground variables included in an earnings function may be interpreted as proxies for early investments in human capital if characteristics of the father and mother are systematically related to the investments in time and goods that they make in their children.

\section{A Causal Model}

Consider a model in which earnings depend upon human capital stocks which are built up over the life cycle through schooling, on-the-job training, and home investment.

By adapting Ben-Porath's well-known model of the acquisition of human capital over the lifetime through investments, we postulate a variant of the Ben-Porath production function for human capital (BenPorath 1967, p. 360 ):

$$
Q_{t}=\beta_{0} S_{t}^{\gamma_{1}} K_{t}^{\gamma_{2}} D_{t}^{\beta_{1}},
$$

where $Q_{t}=$ gross additions to human capital stock in time $t ; K_{t}=$ the stock of human capital existing at $t ; S_{t}=$ the proportion of $K_{t}$ allocated to producing $Q_{t}, 0 \leq S_{t} \leq 1 ; D_{t}=$ the quantity of goods inputs allocated to producing $Q_{t}$; and $\beta_{0}=$ the Hicks neutral-efficiency parameter for producing human capital, $0<\gamma_{1}, \gamma_{2}, \beta_{1}<1$. The rate of change in the capital stock is given by

$$
\dot{K}_{t}=Q_{t}-\delta K_{t},
$$

where $\delta$ is a constant depreciation rate. The stock at time $T$ can be defined as

$$
K_{T}=K_{0}+\int_{t=0}^{T} \dot{K}_{t} d t
$$

where $K_{0}=$ the initial stock or inherent genetic ability.

The marginal-cost curve which corresponds to human capital production function ( 1 ) is shown by Ben-Porath to be

$$
M C_{t}=\frac{a_{0}}{\beta_{0} \gamma_{1}}\left(\frac{\gamma_{1}}{\beta_{1}} \frac{P_{d}}{a_{0}}\right)^{\beta_{1} / \theta} \cdot\left(\frac{Q_{t}}{\beta_{0}}\right)^{\theta} \cdot K_{t}^{\left(\gamma_{1}-\gamma_{2}\right) / \theta},
$$

where $\theta=\left(\gamma_{1}+\beta_{1}\right)$. Thus, the marginal cost of acquiring human capital is a function of existing stocks if $\gamma_{1} \neq \gamma_{2}$. If $\gamma_{1}>\gamma_{2}, M C$ rises with the level of existing stocks, and human capital increases the productivity of time in the market more than the productivity of time in producing new capital. However, if $\gamma_{1}<\gamma_{2}$, the marginal cost of producing new capital falls with existing stocks. The "demand price" depends, however, only on the rental price for human capital, the rates of interest and depreciation, and on the time remaining in the working 


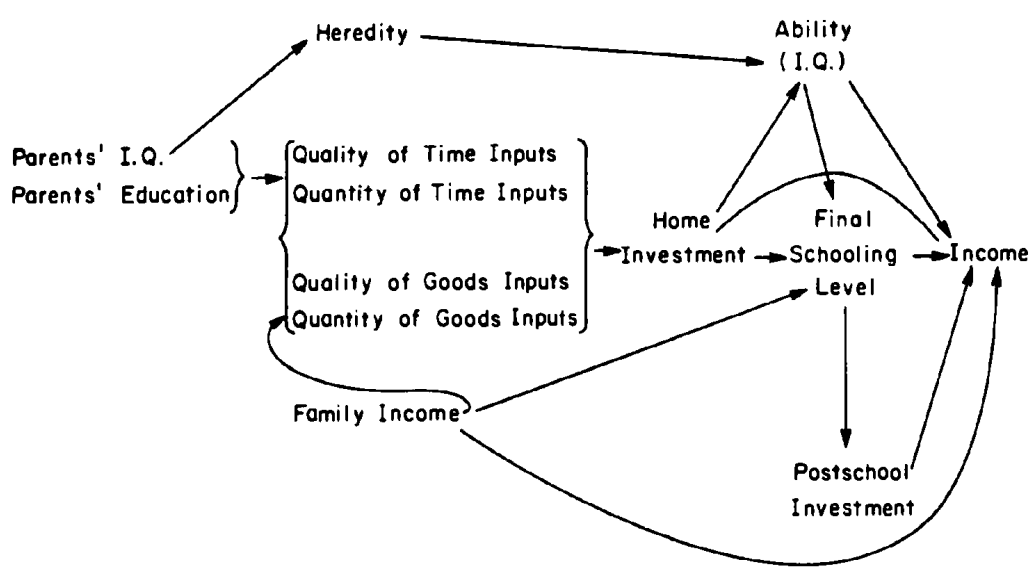

Fig. 1

lifetime. Thus, we would expect persons with greater initial levels of human capital to demand more additions to the stock if $\gamma_{1}<\gamma_{2}$.

Figure 1 helps us to visualize the process. Parents' genetic characteristics determine the heredity of the child. I have shown (Leibowitz 1972) that the quantity of time devoted to children is positively related to parents' education, and there is evidence that the quality of time inputs is also positively related to education (Schoggen and Schoggen 1968). Thus, parents' genetic endowment and their education determine the quality and quantity of time inputs to the child. Parents' attributes also determine family income, which affects the amount and quality of time and goods inputs. These inputs comprise home investment, which, along with heredity, determines IQ. Final schooling level is determined by family income and stocks of human capital. Home investments may affect capital stocks in a manner not reflected in measured IQ. Thus, a variable such as the education of a mother may affect a schooling level both directly and through heredity. Income, which is a rent on the stock of human capital, depends on the four major sources of capital: home investment, measured ability, final schooling level, and postschool investment. This model can be written as a recursive system:

$$
\begin{aligned}
I Q & =f_{1}\left(G, I_{1}\right), \\
I_{2} & =f_{2}\left(I Q, I_{1}, Y_{f}\right), \\
Y & =f_{3}\left(I_{1}, I_{2}, I_{3}, I Q\right),
\end{aligned}
$$

where $G=$ genetic factors, $I_{1}=$ home investment, $I_{2}=$ schooling investment, and $I_{3}=$ postschool investment. 
Clearly, in this system variables which are endogenous in one equation are predetermined in equations of higher number. This is true because the endogenous variables are determined at various early stages of the life cycle. That is, childhood IQ is determined prior to schooling, which is determined prior to earnings. If we assume that disturbances from each pair of equations are uncorrelated in the probability limit, this system may be estimated consistently by the use of ordinary least squares.

The rest of this paper reports an investigation of the possible returns to home investment, concentrating on the following questions:

1. Do home investments add to preschool stocks of human capital, as measured by IQ?

2. Is the amount of schooling achieved affected by early stocks of human capital and by later home investments?

3. Do home investments affect earnings if other forms of human capital are held constant? What is the bias to the coefficient on schooling (the rate of return to schooling) if home investments are omitted from the earnings function?

4. Does an early measure of ability affect earnings if schooling and home investments are held constant? What is the bias to the coefficient on schooling if ability is omitted from the earnings function?

To investigate these questions a unique data set called the Terman sample is used; it is described in Section II. In Sections III-V, the estimation of the childhood human capital, education, and earnings functions is discussed.

\section{The Nature of the Data ${ }^{3}$}

In 1921, Lewis M. Terman, a Stanford University psychologist, initiated a study to evaluate the physical, mental, and personality traits of California school children who scored in the top 1 percent of the national IQ distribution, and to follow those children as far into adult life as possible to see if high IQ was a good predictor of success in later life. (The data generated will be referred to hereafter as the Terman sample.) In 1921 when Terman began to test the children, he selected 1,528 of them with IQ scores of 140 or above, corresponding to the top 1 percent of the intelligence distribution.

The original sample consisted of 857 boys and 671 girls. The larger proportion of males among the group can probably be accounted for by the larger variability in tested IQ among boys than among girls.

3 The data description in this section draws heavily upon discussion in Terman and Oden (1959). I am indebted to Susan Crayne of the National Bureau of Economic Research for devising an ingenious method for decoding the column binary tape of the data and for doing the decoding. 
The method of selection was not free from bias. Budget constraints precluded testing every child in the California schools. Rather, in grades three through eight of schools in urban areas, each classroom teacher listed the three brightest children in the class and the youngest child. These children were further screened by a group IQ test, and the "promising" candidates were given the Stanford-Binet test. The original criterion for inclusion in the study group was a Binet IQ score of 140 or above, although 65 pupils who tested between 135 and 139 were also included. High school students nominated by their teachers as being bright were chosen if their score on the Terman group test fell within the top 1 percent of the distribution. From later evaluations, it was estimated that 90 percent of the eligible children had been included in the sample. The mean IQ of the students on the Stanford-Binet test was 151.5 for boys and 150.4 for girls at the time they were included in the study. Average age of Binet-tested pupils was 9.7 years and that of group-tested high school students was 15.2 years at the time they were selected.

The sample is thus not in any sense representative of California school children in the 1920s. The children were atypical physically and socially as well as intellectually. They tended to be taller and stronger and to mature earlier than their classmates. Fathers of the students had a median 12.4 years of schooling and the mothers, 11.7 years-nearly 4 years above the average for their generation in the United States.

The achievement of sample members also was above average. About 70 percent of the students in the sample finished college as contrasted with 8 percent of the United States population in their cohort. The average earnings of males in the sample in 1960 exceeded those of men of equivalent age and years of schooling by $30-50$ percent.

At the outset, in 1921, in addition to IQ scores, many data about the home backgrounds of the students were collected. Information on the test group members was updated in 1929, 1940, 1950, 1954, and 1960 to include current data on schooling, earnings, occupation, and data on other variables. Although the data collection spanned almost 40 years, the retention rate in the sample was very high. Of the original $1,528^{4}$ sample members, 104 (6.8 percent) died by 1955; after 1928 only 28 were lost track of until, following 1945, six more were not heard from.

\section{Determinants of Ability}

Our discussion up to this point has emphasized that ability as measured by IQ or other similar tests is not only the result of inherited attributes but also of acquired human capital. Although schooling level may affect measured ability, this will not be the case in our analysis, where ability is

\footnotetext{
4 Regressions in this paper are based on the 821 males and 643 females for whom complete childhood records were available. Sample sizes may be further reduced in certain regressions due to missing data.
} 
the childhood IQ score determined in 1921-22. The IQ measure is the score on the Stanford-Binet or Terman group test (TGT).

Several measures of home investment are readily available in the data. The respective educations of the father and the mother are important indices of the quality of the time spent with the child and should be positively related to IQ. In addition, as I have shown elsewhere (Leibowitz 1972), education is also positively related to the quantity of time spent with the child. Since mothers' time expenditures on children exceed those of fathers by at least a factor of $4,{ }^{5}$ we would expect the significance and size of the coefficient of mother's education to exceed that of father's education. However, education of the parents may be a proxy for the quality of genetic inheritance-if intelligence of the parents and their own education are positively correlated, and if intelligence can be transmitted genetically. If education is acting as a proxy for heredity, the coefficient of each parent's education on child's IQ should not differ significantly. A comparison of the size and significance of these two variables will indicate whether parents' schooling is influencing IQ directly through the quality and quantity of time spent with children or whether it is a proxy for inherited ability.

A more direct measure of the quantity of time spent with children in preschool investment results from the parents' estimate in 1922 of how much home instruction they provided their child. Two dummy variables were generated: HOMETR2 = one if parents conducted "an appreciable amount of instruction along particular lines," and zero if they did not; HOMETRI = one if parents spent a "considerable number of hours, but chiefly reading, telling stories, and writing," and zero if they did not do so. The omitted category covered "no instruction, other than usual amount of reading and telling stories."

It is a consistent finding of psychological studies that first children and children from smaller families score higher on IQ tests and achieve more (for instance, get more schooling). The analysis of family investment presents a rationale for this phenomenon, since the more children there are, the less time input parents have available per child. For the same reason children of lower birth order can be expected to receive more time inputs. Both the number of siblings and birth order have been included as proxies for home investments.

In addition, the regressions included a dummy variable equal to one if the IQ test was the Terman group test rather than the Stanford-Binet test. About 33 percent (268) of the male subjects and 26 percent (168) of the females had taken the TGT, in which average scores were 8.5 points below the Stanford-Binet version of the IQ test. Terman's analysis showed

\footnotetext{
3 This is based on 1967 data (Leibowitz 1972). It appears unlikely that in 1922 fathers
} spent more time with children than mothers did. 
the TGT-tested students were at least as select a group as the Binet-tested ones, but scores were shifted down. The assumption is made that the two tests are identical in all other respects. Means and standard deviations of the variables are presented in Appendix C.

\section{A. Estimation for Males}

In table 1 the regression of family-investment variables on IQ measured at age 11 is presented for the 821 males in the sample. Both home-investment variables were positive, with HOMETR2 having a stronger positive impact on IQ than HOMETRl. Thus, the quality of time inputs by parents did raise measured IQ and special instruction had more of an impact than generalized time inputs. Since this holds the quantity of time inputs constant, the education variables can be taken to measure the quality of time. The mother's education is a very significant predictor of IQ, while the coefficient for father's education is not significantly different from zero. This suggests, as argued above, that education is a proxy for home investment and not solely for inherited factors. Psychologists have also shown (Kagan and Moss 1959) that correlation between child's IQ and maternal education is greater than that between child's IQ and paternal education, while the correlations between child's IQ and those of mother and father do not differ significantly.

Birth order is represented by the variable BORDER, which was coded 1 for a first-born child, 2 for the second-born, and so on. This variable thus contains some information about number of siblings as well as about birth order. The negative effect of birth order, while quantitatively small, is quite significant. If, instead of birth order, number of siblings is used, its coefficient is significantly different from zero only at the 10 percent level of significance. If both are included in the equation, birth order's coefficient remains significantly different from zero, while number of siblings does not. Estimated family income in 1922 (YK) did not prove to be a significant predictor of childhood IQ, as seen in table 1 , column 2 .

When the equations are based on the 553 boys who took the StanfordBinet test, thus allowing us to dispense with the TGT dummy variable, the coefficients are substantially the same (see col. 3 , table 1 ).

\section{B. Estimation for Females}

The same variables which accounted for 18.6 percent of the variance in IQ of males in the sample account for only 13 percent of the variance of females' IQ (see table 1, col. 4). Apart from the TGT dummy and family income, none of the variables meets conventional levels of significance. Neither the direct measures of the quantity of time inputs (HOMETRI and HOMETR2) nor the parents' education variables have coefficients 


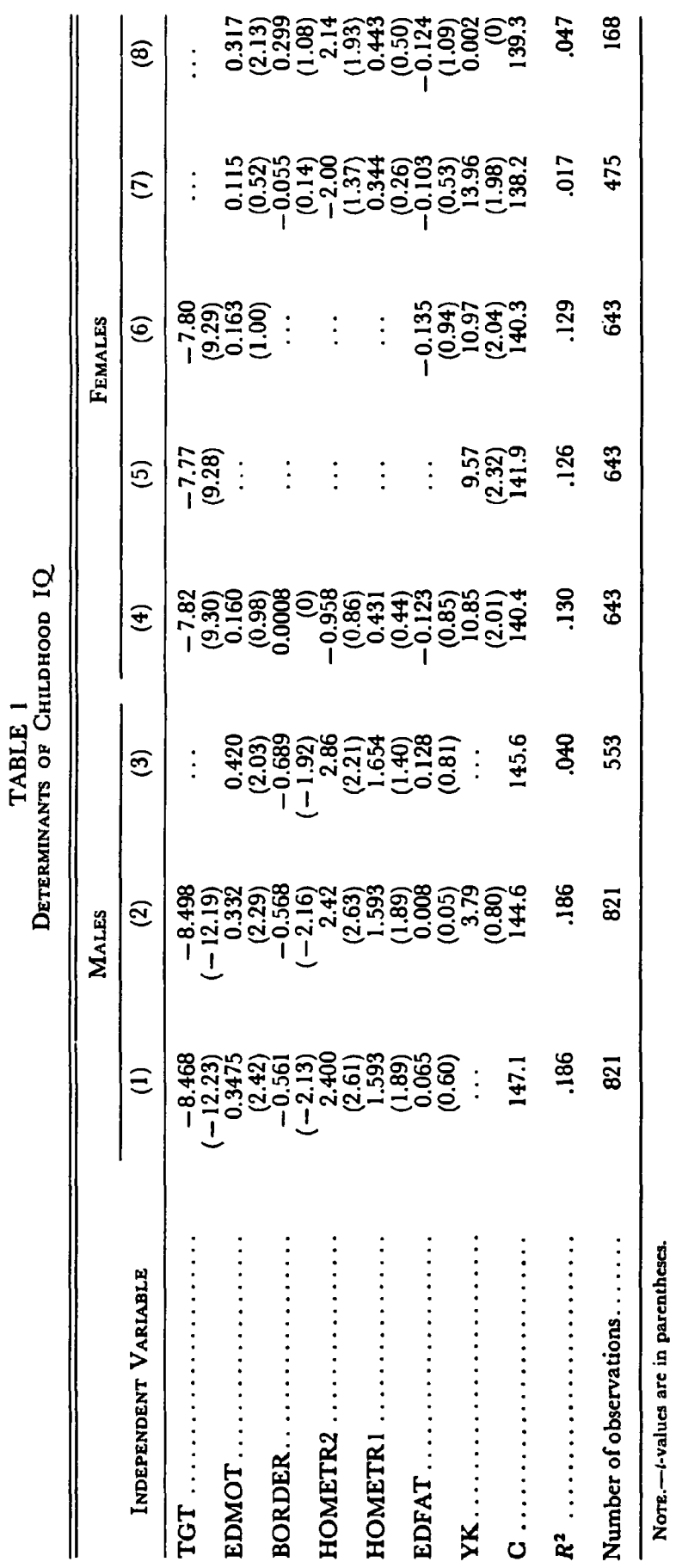


significantly different from zero. Birth order and number of siblings have no significant impact on measured IQ. The only other variable which was significantly related to IQ was YK, a measure of relative family incomes, generated from data on the father's occupation in 1922. (The construction of this latter variable is described in Appendix A.)

When the equation is estimated for only those subjects who took the Stanford-Binet test, the only significant variable is family income (table 1 , col. 7). However, when the sample covers only the girls who took the Terman group test (as in table 1, col. 8), mother's education and HOMETR2 are positively related to childhood IQ as is the case for males, while family income is not significantly related to IQ. It should be noted that the girls chosen by the TGT were older, and probably constituted a more selective group than the girls chosen by the Stanford-Binet test. The ratio of boys to girls in the TGT group was 1.83 and in the StanfordBinet group 1.16 (Terman 1925, p. 560). The greater selectivity of the older group is consistent with the fact that IQ of girls falls more than that of boys over time (Sontag, Baker, and Nelson 1958, pp. 22-32). The TGT group had high abilities which endured at least until their adolescence.

Although a drop in IQ on retest is expected on statistical grounds due to regression toward the mean, girls showed greater decreases in IQ than boys when their IQs were retested after an interval of several years. In this sample, 54 children younger than age 13 in 1927-28 were again given the Stanford-Binet test. The 13-point average decrease in IQ for girls was significantly different from the three-point average drop for boys. ${ }^{6}$

These results suggest that the kind of intelligence that endures through adolescence (as was the case with the TGT-selected girls) is systematically related to home investments. However, in the younger group the factors which account for their scoring in the top 1 percent of the IQ distribution are more evanescent and are not related to home investments. Home investments were related to older girls' IQ differences that were stable over time, but only income was related to younger girls' IQs which faded over time.

\section{Determinants of Schooling Level}

The model postulates that final schooling level depends on ability, family income, and home investments. If human capital is not equally productive in the market and in the acquisition of new human capital, measures of human capital stock (such as childhood IQ) should be related to years of schooling.

\footnotetext{
- The approximate standard deviation of the difference is two (Terman, Burks, and Jensen 1930, p. 25). Four hundred older students also were retested in 1927-28, but the difference by sex was not significant (ibid., p. 33).
} 
The impact of family income on schooling attainment may be quite attenuated in this sample. First, all sample members were residents of California and had access to the "free" state university system, which is of high quality. Second, because of their demonstrated scholastic aptitude, the students without sufficient family resources to finance the indirect costs of schooling would have been eligible for scholarships. Two alternative estimates of parental income were constructed (as described in Appendix A). Further, additional numbers of siblings in a family are assumed to have the effect of reducing the amount of family support for schooling and to indicate lower levels of home investments. The effects of the quantity of preschool home investments (the HOMETR variables) should have been captured in the childhood IQ measure, but measures of home investments made after the childhood IQ test was taken can be expected to have a positive impact on schooling levels. Later home investments may be assumed to be positively correlated with early home investments as well as with parents' education. If the constructed income variable measures family income imperfectly, father's education may be a proxy for income as well as for home investment. (Definitions of schooling levels and their frequencies are given in Appendix B.)

\section{A. Estimation for Males}

Table 2 presents the equations estimating education levels for the 780 males for whom we had 1940 data and the 781 males for whom we had complete 1950 data.

The regressions for both years show that childhood ability is positively related to schooling level. This fact indicates that the kind of human capital that IQ represents enhances productivity in acquiring schooling more than it does productivity in the labor market. This is consistent with the general finding of psychologists that the one thing IQ predicts best is success in school.

Both the education of the mother and of the father are positively and significantly related to schooling achieved, and the coefficients are not significantly different from each other. The effect of other children in the family (SIBS) is negative and significant at the 10 percent level in 1940. By 1950 , the subjects were nearly 40 years old, and the effect of siblings in restricting resources available for schooling seems to have leveled off as other sources of funding were developed.

The quantity-of-home-investment variables are not significantly different from zero at the 10 percent level. Since these variables were important determinants of IQ their negative signs may indicate that intensive training may temporarily boost IQ (as measured at age 11), but that this increase fades as time passes. This, the quantity-of-homeinvestment variables are correlated with a transitory increase in IQ 
TABLE 2

Years of Schooling of Males in Terman Sample

\begin{tabular}{|c|c|c|c|c|}
\hline \multirow[b]{2}{*}{ INDEPENDENT VARIABLE } & \multicolumn{2}{|c|}{1940} & \multicolumn{2}{|c|}{1950} \\
\hline & (1) & (2) & (3) & (4) \\
\hline EDMOT $\ldots \ldots \ldots \ldots \ldots$ & $\begin{array}{l}0.124 \\
(3.05)\end{array}$ & $\begin{array}{r}0.131 \\
(3.18)\end{array}$ & $\begin{array}{r}0.134 \\
(3.35)\end{array}$ & $\begin{array}{r}0.141 \\
(3.47)\end{array}$ \\
\hline EDFAT $\ldots \ldots \ldots \ldots \ldots$ & $\begin{array}{r}0.110 \\
(3.51)\end{array}$ & $\begin{array}{r}0.122 \\
(3.22)\end{array}$ & $\begin{array}{r}0.149 \\
(4.82)\end{array}$ & $\begin{array}{r}0.163 \\
(4.35)\end{array}$ \\
\hline CIQ . & $\begin{array}{r}0.021 \\
(2.16)\end{array}$ & $\begin{array}{r}0.023 \\
(2.29)\end{array}$ & $\begin{array}{l}0.024 \\
(2.46)\end{array}$ & $\begin{array}{r}0.025 \\
(2.57)\end{array}$ \\
\hline TGT $\ldots . .$. & $\begin{array}{r}0.753 \\
(3.54)\end{array}$ & $\begin{array}{r}0.765 \\
(3.59)\end{array}$ & $\begin{array}{r}0.500 \\
(2.38)\end{array}$ & $\begin{array}{r}0.511 \\
(2.43)\end{array}$ \\
\hline HOMETRI . . & $\ldots$ & $\begin{array}{r}-0.192 \\
(0.80)\end{array}$ & $\cdots$ & $\begin{array}{r}-0.124 \\
(0.53)\end{array}$ \\
\hline HOMETR2.. & $\cdots$ & $\begin{array}{r}-0.293 \\
(1.13)\end{array}$ & $\cdots$ & $\begin{array}{r}-0.248 \\
(0.96)\end{array}$ \\
\hline SIBS $\ldots \ldots \ldots$ & $\begin{array}{r}-0.118 \\
(2.01)\end{array}$ & $\begin{array}{r}-0.123 \\
(2.09)\end{array}$ & $\begin{array}{r}-0.058 \\
(1.01)\end{array}$ & $\begin{array}{r}-0.063 \\
(1.08)\end{array}$ \\
\hline YK & $\cdots$ & $\begin{array}{r}-0.782 \\
(0.58)\end{array}$ & $\cdots$ & $\begin{array}{r}-0.929 \\
(0.69)\end{array}$ \\
\hline $\mathrm{C} \ldots \ldots \ldots \ldots \ldots \ldots \ldots \ldots$ & 10.03 & 10.38 & 9.39 & 9.85 \\
\hline$R^{2} \ldots \ldots \ldots \ldots \ldots \ldots \ldots$ & .078 & .080 & .102 & .104 \\
\hline Number of observations... & 780 & 780 & 781 & 781 \\
\hline
\end{tabular}

Norg.- - -values are in parentheses.

which has faded by the time schooling decisions are made. ${ }^{7}$ Family income was not significantly related to schooling levels.

In summary, these regressions indicate that the schooling level for males is positively related to ability, that larger numbers of siblings may cause schooling to take longer to complete due to the difficulty of financing it (or the obligation to put younger brothers and sisters through school), but the final level of schooling is independent of family size. Finally, the levels of parent's education, representing the quality and quantity of home investments, have a positive effect on schooling levels, while the quantity of preschool investments does not. Mother's and father's education have equal impacts on schooling, while mother's education was much more important in determining IQ. Father's education may be a proxy for income, although a more direct measure of income was not significantly related to schooling levels.

\section{B. Estimation for Females}

In contrast to males, schooling levels of females are not significantly related to ability (see table 3 , cols. 1 and 4 .) They are, however, related

7 This transitory effect on IQ of intensive preschool programs has also been seen in programs outside the home, such as Head Start. Finis Welch pointed out this analogy to me. 
TABLE 3

Years of Schooling of Females in Terman Sample

\begin{tabular}{|c|c|c|c|c|c|c|}
\hline \multirow{2}{*}{$\begin{array}{c}\text { INDEPENDENT } \\
\text { Variable }\end{array}$} & \multicolumn{3}{|c|}{1940} & \multicolumn{3}{|c|}{1950} \\
\hline & (1) & (2) & (3) & (4) & (5) & (6) \\
\hline EDMOT & $\begin{array}{r}0.163 \\
(4.67)\end{array}$ & $\begin{array}{r}0.180 \\
(2.89)\end{array}$ & $\begin{array}{r}0.161 \\
(3.77)\end{array}$ & $\begin{array}{r}0.158 \\
(4.73)\end{array}$ & $\begin{array}{r}0.180 \\
(3.01)\end{array}$ & $\begin{array}{r}0.152 \\
(3.70)\end{array}$ \\
\hline EDFAT $\ldots \ldots \ldots$ & $\begin{array}{r}0.085 \\
(273)\end{array}$ & 0.085 & 0.112 & 0.073 & $\begin{array}{r}0.043 \\
(0.79)\end{array}$ & $\begin{array}{l}0.113 \\
(3.70)\end{array}$ \\
\hline CIQ. & $\begin{array}{l}0.011 \\
(1.28)\end{array}$ & $\begin{array}{r}-0.011 \\
(0.36)\end{array}$ & $\begin{array}{l}0.014 \\
(1.51)\end{array}$ & $\begin{array}{r}0.009 \\
(1.15)\end{array}$ & $\begin{array}{r}-0.019 \\
(0.63)\end{array}$ & $\begin{array}{r}0.012 \\
(1.44)\end{array}$ \\
\hline TGT... & $\begin{array}{r}0.669 \\
(3.47)\end{array}$ & $\ldots$ & $\ldots$ & $\begin{array}{r}0.491 \\
(2.65)\end{array}$ & $\ldots$ & $\cdots$ \\
\hline SIBS ... & $\begin{array}{r}-0.136 \\
(2.42)\end{array}$ & $\begin{array}{r}-0.152 \\
(1.62)\end{array}$ & $\begin{array}{r}-0.146 \\
(2.08)\end{array}$ & $\begin{array}{r}-0.126 \\
(2.34)\end{array}$ & $\begin{array}{r}-0.131 \\
(1.47)\end{array}$ & $\begin{array}{r}-0.143 \\
(2.12)\end{array}$ \\
\hline YK . & $\begin{array}{r}1.524 \\
(1.30)\end{array}$ & $\begin{array}{r}0.682 \\
(0.31)\end{array}$ & $\begin{array}{r}0.076 \\
(1.30)\end{array}$ & $\begin{array}{r}1.705 \\
(1.51)\end{array}$ & $\begin{array}{l}1.034 \\
(0.48)\end{array}$ & $\begin{array}{r}0.083 \\
(1.44)\end{array}$ \\
\hline FIRSTBORN ..... & $\begin{array}{r}0.349 \\
(1.97)\end{array}$ & $\begin{array}{r}0.513 \\
(1.60)\end{array}$ & $\begin{array}{r}0.274 \\
(1.26)\end{array}$ & $\begin{array}{r}0.232 \\
(1.36)\end{array}$ & $\begin{array}{r}0.340 \\
(1.10)\end{array}$ & $\begin{array}{l}0.164 \\
(0.79)\end{array}$ \\
\hline C............. & 9.311 & 13.637 & 10.004 & 9.817 & 14.978 & 10.531 \\
\hline$R^{2} \ldots \ldots \ldots \ldots \ldots$ & .166 & .177 & .153 & .154 & .145 & .152 \\
\hline $\begin{array}{c}\text { Number of observ- } \\
\text { ations } \ldots \ldots \ldots \ldots \ldots\end{array}$ & 606 & 158 & 448 & 615 & 158 & 457 \\
\hline
\end{tabular}

Note.-1-values are in parentheses.

to parents' schooling levels. Although the difference between the coefficients on mothers' and fathers' education is greater for the girls than for the boys, this difference is not significant at the 5 percent level. As with males, the more children in the family, the less schooling achieved, but for women the negative effect of a larger family on schooling attainment is not overcome by 1950. Girls who were the oldest child in their family got more schooling, as seen by the positive effect of the variable FIRSTBORN. For boys, once number of siblings was held constant, birth order did not matter. Family income and quantity of home investment in preschool years are not strongly related to years of schooling achieved.

In table 3, columns 2 and 5 refer to the girls selected in high school by the TGT and columns 3 and 6 refer to the Stanford-Binet-selected girls. The mother's education seems to be relatively more important in determining schooling attainment of TGT-girls, while father's education, family income, and number of siblings are relatively more important determinants of schooling for the Stanford-Binet group.

In summary, there is some evidence here that a mother's characteristics have a stronger impact on schooling achieved by females than by males, particularly for the girls chosen in high school. Further, number of siblings and family income are more closely related to females' schooling levels than to those of males, while ability is more strongly related to the males' schooling levels than to those of females. If we apply Becker's analysis (1967, p. 17), these results suggest that for girls the supply curve of funds shifts relative to a comparatively stable demand curve for 
schooling, while the opposite is true for males. This implies that males face greater equality of opportunity for schooling than do females.

\section{Total Effect of Mother's Education}

The total effect of mother's education on schooling achieved is composed of the direct effect and the indirect effect via IQ. For a male, each year of mother's education results in an addition of .14 of a year of schooling in 1940 and .15 of a year in 1950. Thus, the effect of having a mother who is a college graduate compared to one who is a high school graduate is to increase schooling attainment by .6 of a year.

For girls who took the TGT, each additional year of a mother's schooling resulted in .18 of a year of schooling attained in 1940 and .17 of a year in 1950. For the girls who were selected through the StanfordBinet test, an additional year of mother's schooling added .16 of a year to schooling attained by 1940 and .15 of a year to schooling attained by 1950.

\section{Determinants of Income}

\section{A. Schooling and Postschool Investments}

According to the model presented in figure 1 , income is derived from the rent on different forms of human capital: ability and home, school, and postschooling investment. The relation to be estimated is of the form $Y=\beta_{1}+\beta_{2} I_{2}+\beta_{3} I_{3}+\beta_{4}\left(I_{3}\right)^{2}+u$, where $Y=\log$ of earnings in a given year, $I_{2}=$ years of schooling, $I_{3}=$ years of experience, and $u=$ other income-affecting factors which are uncorrelated with the investment variables

Using the approximation that $\log (1+r) \cong r$, and assuming that rates of return are constant over time, the coefficient $\beta_{2}$ can be interpreted as equal to $r K$, where $r$ is the rate of return to investments made in schooling and $K$ is the ratio of investment costs to gross potential earnings during the schooling period. ${ }^{8}$

A common assumption in interpreting human capital earnings functions is that $K=1$, since opportunity costs probably account for the major part of investment costs and part-time earnings are assumed to offset tuition charges. Under these conditions, $\beta_{2}$ can be interpreted as the rate of return to schooling. The inclusion of the number of years of experience and its square results from a Taylor series expansion of a series of on-the-job investments whose ratio to earnings declines linearly with time (see Mincer 1974b, pp. 3-6).

The parameters of the above equation were estimated using data on income earned by men in the sample in 1939, 1949, and 1959. Since

This approach is fully developed by Becker and Chiswick (1966). 
labor-supply data were never obtained, the earnings functions could not be estimated for women in the Terman sample. Only males who were no longer students and who were not unemployed were included in order to achieve as nearly as possible a sample of men who were employed full time.

The dependent variable in 1939 was the full-time monthly wage or salary. For 1949 and 1959, the dependent variable was annual earned income. Years of schooling were assigned to correspond to rather detailed descriptions of schooling level given in the questionnaires (see Appendix B). Experience was calculated as: age - age at high school graduation (final education level -12). If we employ the useful assumption that $K=1$, the regression results presented in column 1 of tables 4-6 imply a rate of return to schooling of between 5.6 and 6.7 percent. This is low compared with other estimates of rates of return to college graduates.

Rates of return calculated for graduate training are usually lower than those for bachelor of arts degree holders, and 44 percent of this sample had more than 16 years of schooling. There is also reason to believe that the assumption that $K=1$ is less tenable for this sample than for the average college graduate, since 24 percent of the Terman undergraduates had scholarships or fellowships amounting to $\$ 200$ or more and 10 percent had received $\$ 1,000$ or more in support of their studies. If $K<1$, $\beta_{2}<r$, thus coefficients on years of schooling appear to be underestimates of the rate of return to education for this sample.

TABLE 4

Earnings Functions for Males in 1940

\begin{tabular}{|c|c|c|c|c|}
\hline & \multicolumn{4}{|c|}{ Log of Monthly Earnings (\$) } \\
\hline & (1) & (la) & (2) & (3) \\
\hline Years of schooling in $1940 \ldots \ldots$ & $\begin{array}{r}0.056 \\
(5.18)\end{array}$ & $\begin{array}{r}0.056 \\
(5.18)\end{array}$ & $\begin{array}{r}0.063 \\
(5.77)\end{array}$ & $\begin{array}{r}0.063 \\
(5.22)\end{array}$ \\
\hline Years of experience in $1940 \ldots \ldots$ & $\begin{array}{r}0.004 \\
(0.07)\end{array}$ & $\begin{array}{r}0.019 \\
(2.70)\end{array}$ & $\begin{array}{r}0.019 \\
(2.75)\end{array}$ & $\begin{array}{r}0.026 \\
(2.87)\end{array}$ \\
\hline$(\text { Years of experience })^{2} \ldots \ldots \ldots$ & $\begin{array}{l}0.0003 \\
(0.27)\end{array}$ & $\ldots$ & $\ldots$ & $\cdots$ \\
\hline Mother's education. ........... & $\ldots$ & $\cdots$ & $\begin{array}{l}-0.016 \\
(-1.52)\end{array}$ & $\cdots$ \\
\hline Father's education $\ldots \ldots \ldots \ldots$ & $\cdots$ & $\cdots$ & $\begin{array}{l}-0.009 \\
(-0.91)\end{array}$ & $\cdots$ \\
\hline YK $\ldots \ldots \ldots \ldots \ldots \ldots \ldots \ldots$ & $\cdots$ & $\cdots$ & $\begin{array}{r}0.85 \\
(2.41)\end{array}$ & $\cdots$ \\
\hline Family income adequacy ........ & $\cdots$ & $\cdots$ & $\begin{array}{r}0.050 \\
(3.40)\end{array}$ & $\cdots$ \\
\hline CIQ $\ldots \ldots \ldots \ldots \ldots \ldots \ldots \ldots$ & $\ldots$ & $\cdots$ & $\ldots$ & $\begin{array}{l}-0.001 \\
(-0.46)\end{array}$ \\
\hline TGT .... & $\cdots$ & $\cdots$ & $\cdots$ & $\begin{array}{r}-0.10 \\
(-1.36)\end{array}$ \\
\hline Intercept $\ldots \ldots \ldots \ldots \ldots \ldots \ldots$ & 4.424 & 4.247 & 3.529 & 4.169 \\
\hline$R^{2}$ & .036 & .036 & .063 & .038 \\
\hline
\end{tabular}

Source.-Calculated from the Terman sample; includes 724 observations.

NOTE.- $t$-values are in parentheses. 
TABLE 5

Earnings Functions for Males in 1950

\begin{tabular}{|c|c|c|c|}
\hline & \multicolumn{3}{|c|}{ Log of Annual Earnings (\$100) } \\
\hline & (1) & (2) & (3) \\
\hline Years of schooling in $1950 \ldots \ldots \ldots \ldots$ & 0.062 & 0.064 & 0.064 \\
\hline Years of experience in $1950 \ldots \ldots \ldots \ldots$ & $\begin{array}{l}(0.14) \\
0.131\end{array}$ & $\begin{array}{l}(b .29) \\
0.138\end{array}$ & $\begin{array}{l}(5.79) \\
0.128\end{array}$ \\
\hline${\text { (Years of experience })^{2} .}^{2}$ & $\begin{array}{r}(2.39) \\
-0.0018\end{array}$ & $\begin{array}{r}(2.52) \\
-0.0019\end{array}$ & $\begin{array}{r}(2.34) \\
-0.0017\end{array}$ \\
\hline & $(-2.19)$ & $(-2.32)$ & $(-2.06)$ \\
\hline Mother's education.. & $\ldots$ & $\begin{array}{l}-0.026 \\
(-2.56)\end{array}$ & $\ldots$ \\
\hline Father's education .. & ... & $\begin{array}{r}0.00075 \\
(0.08)\end{array}$ & $\cdots$ \\
\hline YK . . & $\cdots$ & $\begin{array}{r}0.655 \\
(2.00)\end{array}$ & $\cdots$ \\
\hline CIQ ...... & $\cdots$ & $\cdots$ & $\begin{array}{r}0.00049 \\
(0.20)\end{array}$ \\
\hline TGT ....... & $\cdots$ & $\cdots$ & -0.033 \\
\hline Intercept $\ldots \ldots \ldots$ & 1.02 & 0.567 & 0.905 \\
\hline 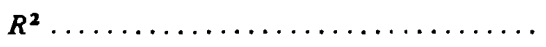 & .061 & .073 & .062 \\
\hline
\end{tabular}

Sourcz.-Calculated from the Terman sample; includes 731 observations. Note.- - -values are in parentheses.

TABLE 6

Earnings Fungtions for Males in 1960

\begin{tabular}{|c|c|c|c|}
\hline & \multicolumn{3}{|c|}{ Log of AnNual Earnings ( $\$ 100)$} \\
\hline & (1) & (2) & (3) \\
\hline Years of schooling in $1950 \ldots \ldots \ldots \ldots \ldots$ & $\begin{array}{r}0.067 \\
(681)\end{array}$ & $\begin{array}{r}0.067 \\
(6.63)\end{array}$ & $\begin{array}{r}0.075 \\
(6.93)\end{array}$ \\
\hline Years of experience in $1960 \ldots \ldots \ldots \ldots$ & $\begin{array}{r}0.097 \\
(1.44)\end{array}$ & $\begin{array}{l}0.104 \\
(1.54)\end{array}$ & $\begin{array}{r}0.089 \\
(1.31)\end{array}$ \\
\hline (Years of experience) ${ }^{2} \ldots \ldots$ & -0.001 & -0.001 & -0.001 \\
\hline Mother's education. . & $\begin{array}{c}(-1.43) \\
\ldots\end{array}$ & $\begin{array}{l}(-1.04) \\
-0.016 \\
(-1.58)\end{array}$ & $\begin{array}{c}(-1.18) \\
\cdots\end{array}$ \\
\hline Father's education $\ldots \ldots \ldots \ldots \ldots \ldots \ldots$ & $\cdots$ & $\begin{array}{r}-1.001 \\
0.001 \\
(1.05)\end{array}$ & $\cdots$ \\
\hline YK $\ldots \ldots \ldots$ & $\cdots$ & $\begin{array}{c}0.263 \\
(0.84)\end{array}$ & $\cdots$ \\
\hline CIQ $\ldots \ldots \ldots \ldots$ & $\cdots$ & $\cdots$ & $\begin{array}{r}0.002 \\
(0.86)\end{array}$ \\
\hline TGT $\ldots \ldots \ldots \ldots \ldots \ldots \ldots \ldots \ldots \ldots \ldots$ & $\cdots$ & $\cdots$ & -0.096 \\
\hline Intercept $\ldots \ldots \ldots$ & 1.722 & 1.411 & 1.33 \\
\hline$R^{2}$ & .091 & .097 & .097 \\
\hline
\end{tabular}

Source.-Calculated from the Terman sample; includes $\mathbf{7 0 1}$ observations. Note. - $?$-values are in parentheses. 
There is, however, a striking constancy in the schooling coefficients from decade to decade. The experience variables are not significant in explaining 1940 incomes (the subjects were, on the average, 29 years old). At this stage in the life cycle, experience may be exerting a linear rather than parabolic effect on earnings, as indicated in column la, table 4.

\section{B. Home Investments}

What is the effect of expanding this earnings function to include home investment variables? The equation to be estimated is of the form

$$
Y=\beta_{1}^{\prime}+\beta_{2}^{\prime} I_{2}+\beta_{3}^{\prime} I_{3}+\beta_{4}^{\prime}\left(I_{3}\right)^{2}+\beta_{5} I_{1}+V,
$$

where $I_{1}=$ the amount of home investment and all other variables are defined as above.

It is clear that if home investments affect income and if home investment and schooling are positively correlated, then the simple regression of income on schooling results in a coefficient on schooling which is biased upward from $\beta_{2}^{\prime}$ by a factor equal to $\beta_{5} r_{I_{1}, I_{2}}$, where $r_{i, j}$ is the regression coefficient of variable $i$ on variable $j$ in the sample. However, if home investments do not directly influence income, but affect it only indirectly by influencing schooling levels, then the coefficient $\beta_{2}$ is not biased upward from $\beta_{2}^{\prime}$.

Estimates of equation (5) for 1940, 1950, and 1960 are presented in column 2 of tables 4-6. Father's education was not significantly related to earnings in any one of the three years. Mother's education was negatively related to earnings in all 3 years, and in 1950 this coefficient was significantly different from zero. Mother's education was positively correlated with the two family-income measures (correlation with $\mathrm{YK}=.43$, correlation with family income adequacy $=.16$ ). Both familyincome measures were quite significantly related to 1940 income. In 1950 , only YK was significantly related to income, and by 1960 neither income measure was. Thus, the effect of parents' income on earnings is attenuated over the life cycle. Family-income variables are related to quality of college attended, and this may, in turn, affect earnings (see Wachtel 1974). Of those who had "abundant incomes," 63 percent attended Stanford; in contrast, only 27 percent of those with "limited" incomes and 36 percent of those with "adequate" incomes did so. Greater percentages of the lower-income groups attended state colleges rather than the higher-quality state universities.

Mother's education and YK are positively correlated with own years of schooling ( $\rho=.23, \rho=.17$, respectively) and FAMINC is negatively related $(\rho=-.02)$. The net effect of the home-background variables is to increase the coefficient on years of schooling from .056 to .063 in 1940, 
although the YK variable is significantly related to 1940 income. The years-of-schooling coefficient is virtually unchanged by the inclusion of background variables in 1950 and 1960 .

These findings provide some evidence against the hypothesis advanced by Bowles (1972) that specification errors and errors in measurement of family-background variables lead (because these variables are positively correlated with schooling level) first to overestimating the importance of schooling; and second, to underestimating the importance of background variables in the earnings function.

Bowles maintains that because data on parents' education, occupations, and incomes are obtained from questionnaires administered many years after the fact "the degree of error in the measurement of the father's occupation and education variable greatly exceeds that in the respondent's own years-of-schooling variable" (1972, p. S227). Consequently, the importance of background variables will be underestimated, while that of the respondent's own schooling will be overestimated. The Terman data allow a simple test of the proposition that if background and the sample member's own data were subject to similar levels of error, the background variables would increase in significance while the member's own variables would fall. In the Terman sample, data on parents' education and home investment were supplied by parents when the child was 11 years old. Yet, in spite of the significance of some of these variables, the importance of the years-of-schooling variable was not reduced.

\section{Ability}

Using the same reasoning applied to the home-investment variables, we can say that if ability affects earnings and if it is positively correlated with schooling achieved, omitting this variable in the earnings function results in biasing upward the rate of return to schooling.

Income in 1940,1950 , and 1960 is not significantly related to IQ, holding schooling and experience constant (see col. 3 of tables 4-6). The IQ variables remain insignificant if both home investment and IQ variables are included in the earnings function, while the coefficients on the schooling and experience terms are virtually unchanged. We conclude that childhood ability has very little independent effect on earnings. It is to be expected that earnings are related to contemporaneous stocks of human capital. In this sample, years of schooling in 1940 is no doubt a better index of human capital in 1940 than is IQ measured in 1922.

Furthermore, it must be recalled that due to the nature of the sample, we are considering marginal differences in ability within the top 1 percent of the ability distribution. Yet, IQ scores varied for this group from 135 to 200 , while a standard deviation for the IQ distribution is 15 points and IQ was a significant determinant of schooling. 
With a less restricted sample, Griliches and Mason (1972) who used data on United States military veterans who were younger than 35 years, also found the inclusion of an ability measure did not greatly change the coefficient of schooling. Using the change in schooling level after military service, they concluded that the bias in this coefficient due to the omission of an ability variable (AFQT) was only about 12 percent. In their sample, in contrast with this study, the ability variables were significant, although they did not greatly change the schooling coefficient.

Several other studies have also found relatively small bias due to omission of ability variables. Ashenfelter and Mooney (1968, p. 86), in a study of past recipients of Woodrow Wilson fellowships, found that the "inclusion of an ability measure affected the estimates of the coefficients for the other education related variables only in a very marginal fashion." Weisbrod and Karpoff (1968), roughly controlling for ability in a sample of employees of the American Telephone and Telegraph Company, estimate that only one-fourth of the earnings' differences between high school and college graduates is attributable to nonschooling factors rather than to differences in schooling level.

Taubman and Wales (1973) found, after testing several ability measures, that in the NBER-Thorndike sample of United States Air Force volunteers for certain programs, only the omission of mathematical ability affected the schooling parameters. They estimate that the bias to the education coefficient from omitting the mathematical-ability variable was about 25 percent for 1955 incomes and 15 percent for 1969 incomes. Using unpublished data from Dael Wolfle on Minnesota high school graduates, Taubman and Wales found a bias of "no more than four per cent at the various educational levels" from omitting ability measures from the earnings function.

John Hause (1972) found that the effect of ability on log of income remained small at all schooling levels when he used data from Project Talent which tested a sample of high school students and later surveyed their earnings. He calculated upward bias in the education coefficient, if ability is omitted, at 13-18 percent in Daniel Rogers's (1969) data based on a sample of Connecticut school boys, and at 3-11 percent in the Thorndike data.

\section{Summary}

Because of the unique nature of the sample, the findings on the Terman data cannot be readily generalized to the population as a whole. However, several conclusions can be drawn:

1. It has been demonstrated that home investments do increase measured stocks of childhood human capital. Even within a sample of 
very able children, home-investment variables were positively and significantly related to a measure of human capital, IQ, for boys and for a subset of older girls. A mother's education was significantly related to IQ, while the father's was not, thus indicating that home investments rather than wholly genetic factors underlie the relationship.

2. Education achieved by age 29 and age 39 by men and women in the Terman sample did depend on parents' education and on family size, but not on a more direct measure of the quantity of preschool time inputs or on family income. Boys' achievement also depended on ability, indicating greater equality of opportunity for boys to get schooling than for girls.

3. Men's earnings at ages 29, 39, and 49 were strongly related to schooling and experience variables. The addition of home-investment and ability variables did not significantly decrease the coefficients on schooling and experience, although family income was positively and significantly related to earnings in the early years of the life cycle.

\section{Appendix A}

\section{Measures of Family Income}

Two measures of family income were examined in this study. One was a subjective measure; the other was constructed from data on fathers' occupations in 1922.

A. The subjective measure, family income adequacy, resulted from the answer given in 1950 to the following question: "How adequate were family finances during your childhood and youth?" Answers were coded as follows:

\begin{tabular}{cc}
\hline Coding & Frequency (in \%) \\
\hline $1=$ limited or very limited $\ldots \ldots \ldots \ldots$ & 20.9 \\
$2=$ adequate $\ldots \ldots \ldots \ldots \ldots \ldots \ldots \ldots$ & 75.0 \\
$3=$ abundant $\ldots \ldots \ldots \ldots \ldots \ldots$ & 4.1 \\
\hline
\end{tabular}

B. An alternative estimate of 1922 family income was derived from the father's 1922 occupation, reported as one of six categories. Estimates of income for various occupation groups were derived from King (1923, p. 111) since the United States Census did not collect income data by occupation until 1940. King's estimates were based on average earnings for a sample of 436 employed males between December and February 1922.

The ratio of income in each category to the income of professional workers is presented below:

\begin{tabular}{|c|c|c|}
\hline & Terman Category & YK \\
\hline $\begin{array}{l}1 . \\
2 . \\
3 . \\
4 . \\
5 .\end{array}$ & $\begin{array}{l}\text { Professional . . . . . . . . . . . . . . . } \ldots \ldots \ldots \ldots \\
\text { Semiprofessional, higher business } \ldots \ldots \ldots \ldots \ldots \\
\text { Clerical, skilled trades, retail business. } \ldots \ldots \ldots \ldots \\
\text { Farming and agriculture } \ldots \ldots \ldots \ldots \ldots \\
\text { Semiskilled trades, minor clerical, or business } \ldots \\
\text { Slightly skilled trades, little training } \ldots \ldots \ldots \ldots\end{array}$ & $\begin{array}{l}1.00 \\
0.90 \\
0.82 \\
0.78 \\
0.72 \\
0.64\end{array}$ \\
\hline
\end{tabular}


TABLE B1

Years of Schooling in the Terman Sample, Description, and 1950 Frequencies for Males and Females

\begin{tabular}{|c|c|c|c|c|c|}
\hline \multirow{2}{*}{$\begin{array}{c}\text { Years of } \\
\text { SchoOL Coded }\end{array}$} & \multirow[b]{2}{*}{ Highest Level of Schooling } & \multicolumn{2}{|c|}{ MALES } & \multicolumn{2}{|c|}{ Females } \\
\hline & & Number & $\%$ & Number & $\%$ \\
\hline $\begin{array}{l}10 \ldots \ldots \ldots \ldots \\
12 \ldots \ldots \ldots \ldots\end{array}$ & $\begin{array}{l}\text { High school, } 1-3 \text { years .......... } \\
\text { High school, } 3 \text { years plus business } \\
\text { or trade school; high school }\end{array}$ & 7 & 0.9 & 9 & 1.4 \\
\hline $13 \ldots \ldots \ldots$ & $\begin{array}{l}\text { High school graduate plus 1-2 } \\
\text { years of art, music, business, } \\
\text { normal, technical, or trade } \\
\text { school, or less than } 2 \text { years of }\end{array}$ & 59 & 7.2 & 63 & 9.8 \\
\hline 14 & $\begin{array}{l}\text { college } \\
\text { High school graduate plus phar- } \\
\text { macy, chiropractic, accounting, } \\
\text { or nursing school or } 2 \frac{1}{2}-3 \text { years }\end{array}$ & 65 & 7.9 & 54 & 8.4 \\
\hline 15 & $\begin{array}{l}\text { of college } \\
\text { High school plus 3-4 years of art }\end{array}$ & 86 & 10.5 & 70 & 10.9 \\
\hline & or music school or college & 5 & 0.6 & 1 & 0.2 \\
\hline 17. & $\begin{array}{l}\text { B.A. } \\
\text { Masters' degrees or 5-6 year en- }\end{array}$ & 200 & 24.3 & 186 & 28.9 \\
\hline 18 & $\begin{array}{l}\text { gineering or architecture deg- } \\
\text { rees } \\
\text { D.D.S. with B.A., M.B.A., grad- }\end{array}$ & 138 & 16.8 & 213 & 33.1 \\
\hline $\begin{array}{l}19 . \\
20 . \\
21\end{array}$ & $\begin{array}{l}\text { uate work of } 2 \text { years } \\
\text { J.D. or L.L.B with B.A. } \\
\text { Ph.D., Ed.D., L.L.D., etc. } \\
\text { M.D. } \\
\text { Incomplete information }\end{array}$ & $\begin{array}{l}20 \\
87 \\
74 \\
45 \\
36\end{array}$ & $\begin{array}{r}2.4 \\
10.6 \\
9.0 \\
5.5 \\
4.4\end{array}$ & $\begin{array}{r}1 \\
2 \\
13 \\
6 \\
25\end{array}$ & $\begin{array}{l}0.2 \\
0.3 \\
2.0 \\
0.9 \\
3.9\end{array}$ \\
\hline
\end{tabular}


TABLE Cl

Means and Standard Devitions-Males

\begin{tabular}{|c|c|c|}
\hline Variable & Mean & Standard Deviation \\
\hline 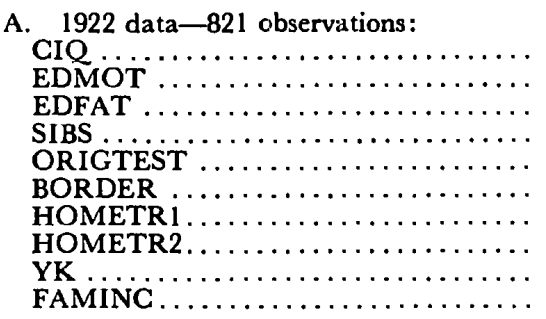 & $\begin{array}{r}148.88 \\
11.74 \\
12.36 \\
1.85 \\
0.33 \\
1.89 \\
0.19 \\
0.15 \\
0.88 \\
1.82\end{array}$ & $\begin{array}{r}10.36 \\
2.71 \\
3.53 \\
1.58 \\
0.47 \\
1.24 \\
0.40 \\
0.36 \\
0.09 \\
0.48\end{array}$ \\
\hline 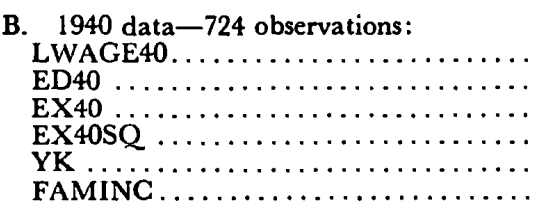 & $\begin{array}{r}5.60 \\
16.11 \\
8.82 \\
92.92 \\
0.88 \\
1.81\end{array}$ & $\begin{array}{r}0.67 \\
2.65 \\
3.90 \\
75.63 \\
0.09 \\
0.48\end{array}$ \\
\hline 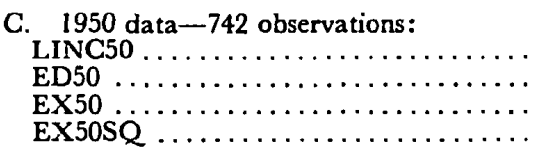 & $\begin{array}{r}4.30 \\
16.38 \\
18.18 \\
348.69\end{array}$ & $\begin{array}{r}0.81 \\
2.59 \\
4.27 \\
155.79\end{array}$ \\
\hline 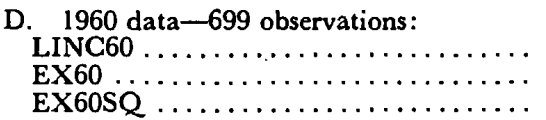 & $\begin{array}{r}4.91 \\
28.16 \\
811.51\end{array}$ & $\begin{array}{r}0.60 \\
4.31 \\
243.27\end{array}$ \\
\hline
\end{tabular}

TABLE C2

Means and Standard Deviations-Females

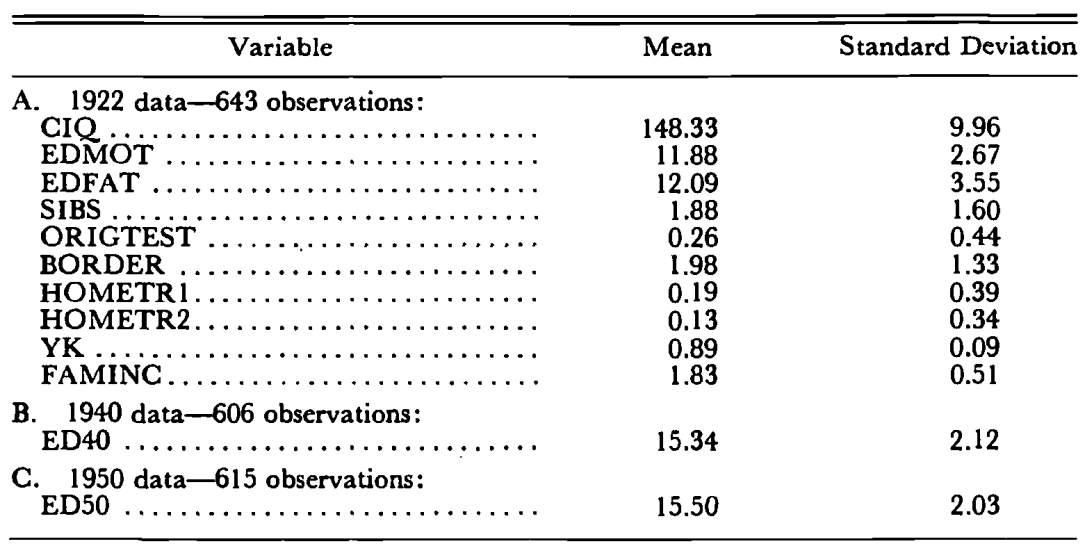




\section{Comment}

\section{Frank P. Stafford}

University of Michigan

The Leibowitz study is important because, through the use of homeinvestment variables, it goes beyond the usual practice of recording that parental education and income should in some fashion influence the lifetime-earnings potentials of individuals. As the study suggests, data requirements for research on home investments are rather demanding because such final output measures as adult earnings are not often available along with measures of home and school investments. Moreover, the position advanced and given considerable empirical support is that the family investments end up as being a type of intermediate good. The intermediate-good argument is crucial to the analysis, for it suggests that simply taking measures of human capital for adults (education and labormarket experience) and tacking on variables for home investments may suggest only a minor influence of the latter which would likely be subsumed in measures of adult skills.

While the author has demonstrated that home investments substantially affect adult earnings, there are several theoretical and empirical problems with the current effort which may be remedied in future research.

It would seem that to pursue seriously the specification of a dynamic accumulation model starting at childhood (even given an exogenous family size and earnings potential of the parents) would require something more than Ben-Porath's model of investment in human capital. For if $K_{0}$ is the initial condition of "inherent genetic ability," it seems unlikely that preschoolers choose, or that parents can make them choose, a time path of training so as to maximize the present value of net earnings. To a large extent, the investments in preschoolers are organized by their parents, and this preschool investment determines an intermediate good. This intermediate good then contributes to the learning process at the ' point when the child begins to make independent investment decisions with his parents' resources defining a financial constraint or marginal cost 
of funds. A variety of specifications, such as having the intermediate good an argument in the production function or altering the efficiency parameter, could be used. This general specification would be more in keeping with the empirical work in the paper and would separate conceptually the role of parents and children in determining educational attainment.

A more difficult theoretical problem is hidden in the recursive model used. While a model of this type has much to recommend it on grounds of estimation, the critical factors influencing home investment in children include number of children in the family and the quantity and quality of home investments as well as other training given to particular children. That is, the process of investment in children is bound up with the family decision on number of children. On a descriptive level it may be sufficient to treat the number of children as exogenous and observe how variations in parental input influence educational attainment, given family income. Yet, the decision making by the family requires a delicate balancing of number of children and lifetime family income by virtue of the very high (dynamic) shadow price of the wife's withdrawal from the labor force, particularly for highly educated young women. Although these decisions can be portrayed by a complex model, there is much merit in a less ambitious (realistic?) approach which takes the family size and home investments per child as given. The point of reference to a model with a demographic sector is to emphasize that the approach in the Leibowitz paper must be utilized with some uneasiness insofar as it glosses over a large and important question of family behavior: How do parents decide number of children and home inputs per child?

On the empirical side, the major data limitations are that in the Terman sample there is only minimal variation in several of the critical variables (IQ has a mean of 149 with a standard deviation of only 10 ) and that the variables measuring home training, HOMETR1 and HOMETR2, are rather vague. It seems tenuous to argue that the difference between (1) "no instruction, other than usual amount of reading and telling stories" and (2) "considerable number of hours, but chiefly reading, telling stories and writing" or between (1) and (3) "an appreciable amount of instruction along particular lines" really constitutes a measure of the quantity of time inputs by the parents. Yet, this is in fact assumed because use of these variables, it is argued, "holds the quantity of time inputs constant, [and] the education variables can be taken to measure the quality of time." This is all the more difficult to believe since recent work (Leibowitz 1972; Hill and Stafford 1974) strongly suggests that quantity of time inputs to children by more-educated women is greater than for less-educated women within a lifetime income group.

Without distinguishing between quality or quantity of home inputs per child, the finding, verified in other studies, that education of the wife is much more important than education of the husband (or IQ of the 
mother) in determining IQ of the child implies that there is a large nongenetic component to IQ. More significantly, this nongenetic component which can be related to home investment influences educational attainment. This is a first major step in the direction of showing that home investments constitute an intermediate form of human capital which influences education. The second step is the demonstration that the IQ and parental-education variables (home investment proxies) influence educational attainment. The third step is to show that education influences earnings but that the home investment variables have no direct influence on earnings. This finding corroborates recent work for a national probability sample wherein each year of a father's education results in a .3 increase in the years of schooling of his sons, but the earnings of sons are not directly influenced by education of the father (Johnson and Stafford 1973, pp. 145 and 151).

A secondary theme developed in the paper is the issue of upward bias in educational variables owing to measurement error attributable to imperfect memory or subjective recall in background variables. With minor error in the background variables because the information was obtained from parents when the child was 11 years old, it is found that the influence of the child's own schooling is not appreciably lowered. These results are interpreted as contradicting the contention that most research understates the importance of background variables (Bowles 1972). Yet, aside from the issue of measurement errors, the model used here specifies that parental variables influence home investment and therefore have a major, though indirect, influence on adult earnings. This and other research (Griliches and Mason 1972; Johnson and Stafford 1973) constitute an empirical link in understanding the rule of intergenerational influences on the income distribution.

To conclude, let me mention two topics on which this study has a bearing. The observed positive correlation between spouses' educations can be interpreted as a mutual consumption choice and the return to education of women is, under this view, partly realized in this fashion (though Veblen interpreted this consumption as a vestigial form of predatory activity). In the Leibowitz study, one of the major returns to education of women is in the form of home investments in children. An interesting study would be to develop value-added figures and combine these with earnings data to calculate returns to schooling for women. This would show, I believe, that earnings differentials between educated men and women are considerably offset by nonmarket productivity differences.

The efficacy of public policy as a vehicle for altering the income distribution is limited since, it is said, income is so strongly influenced by parental background that opening better schooling opportunities will not have any appreciable effect on earnings for those born into low-income families. In this light, do the different forms of income maintenance, by 
allowing more home time by the mother, result in larger home investments in the children? If the answer is yes, there is reason to believe that public policy can influence what appears to be an important source of human capital formation. 